\title{
Faktor Risiko yang Mempengaruhi Kepatuhaan Terapi Antiretroviral (ARV) pada Pasien HIV/AIDS di RSUD Abepura Jayapura
}

\author{
Konstantina Pariaribo*,Suharyo Hadisaputro ${ }^{* *}$, Bagoes Widjanarko ${ }^{* * *}$, Muchlis AU \\ Sofro ${ }^{* * * * *}$,Sakundarno Adi** \\ "Fakultas Kesehatan Masyarakat Universitas Cendrawasih," Politeknik Kesehatan Semarang, ${ }^{* * *}$ Fakultas \\ Kesehatan Masyarakat Universitas Diponegoro, ${ }^{* * * *}$ Fakultas Kedokteran Universitas Diponegoro
}

\begin{abstract}
Background: HIV/AIDS is a major problem in many countries. Antiretroviral (ARV) has become the solution for preventing the pandemic disease. This research aimed to find out risk factors, which affected the HIV/AIDS patients adherence to the antiretroviral (ARV) therapy. The research took place at RSUD Abepura in Jayapura.

Method: The research applied an analytical observational design with a case control, which was supported by qualitative data. There were 86 respondents involved, consisting of 43 case and 43 control respondents. Samples collection used a Simple Random Sampling. Instruments used for this study were questioners and indepth interviews. Data analysis included univariate and bivariate analyses using a chi-square test. In addition, it also performed a multivariate analysis using logistic regression test.

Results: The research found three risk factors that affected the HIV/AIDS patients adherence to ARV: occupation $(\mathrm{p}=0.005 ; \mathrm{OR}=4.472 ; 95 \% \mathrm{CI}=1.633-12.245)$, inaccessibility to health care center $(\mathrm{p}=0.008 ; \mathrm{OR}=3.675 ; 95 \% \mathrm{CI}=1.476-9.146)$, lacking family supports $(\mathrm{p}=0.013 ; \mathrm{OR}=$ $3.606 ; 95 \% \mathrm{CI}=1.398-9.146)$. Other factors, sex, age, knowledge, apathetic manner, side-effect history, therapeutic tenure, ethnic background, counseling personnel, health care provider attitude, religious approach, alternative medicine intake, and herbal medicine use, did not have significant affects.
\end{abstract}

Conclusion: Factors that affected the ARV therapy adherence were occupation, inaccessibility to health care center, and lacking family supports.

Keywords: Riskfactors; Adherence; Antiretroviral; HIV/AIDS.

*Penulis korespondensi : tinapariaribofkmuncen@gmail.com 


\section{Pendahuluan}

HIV (Human Immunedeficiency Virus) merupakan virus yang menyerang sistem kekebalan tubuh sehingga tubuh rentan terhadap berbagai penyakit.' Acquired immune deficiency syndrome (AIDS) dapat diartikan sebagai kumpulan gejala atau penyakit yang disebabkan oleh menurunnya kekebalan tubuh akibat infeksi oleh virus HIV, khususnya menyerang limfosit $\mathrm{T}$ serta menurunnya jumlah CD4 yang bertugas melawan infeksi. AIDS merupakan tahap akhir dari infeksi HIV. ${ }^{1,2}$

Estimasi UNAIDS pada tahun 2011 orang yang hidup dengan HIV sebanyak 34 juta orang dan yang meninggal sebanyak 1,7 juta orang dari penduduk dunia. Diperkirakan $0,8 \%$ orang dewasa usia 15-49 tahun hidup dengan HIV/AIDS. Tahun 2012 ada peningkatan jumlah penderita HIV dari tahun 2011 menjadi 35,5 juta jiwa dan yang meninggal mengalami penurunan dari tahun sebelumnya menjadi 1,6 juta jiwa. ${ }^{3}$

Prevalensi HIV/AIDS di Indonesia telah bergerak dengan laju yang sangat mengkhawatirkan, hampir semua provinsi di Indonesia ditemukan kasus HIV/AIDS. Permasalahan HIV/AIDS telah sejak lama menjadi isu bersama yang terus menyedot perhatian berbagai kalangan, terutama sektor kesehatan. ${ }^{4}$

Secara kumulatif mulai dari 1 April 1987 sampai dengan Desember 2013 jumlah penderita HIV 127. 416 kasus dan AIDS 52.348 kasus. Peningkatan kasus HIV/AIDS di Indonesia diakibatkan faktor risiko penularan yang masih tinggi. Berdasarkan Laporan Ditjen PP \& PL Kemenkes RI sampai dengan bulan Desember tahun 2013 penyebaran kasus AIDS paling tinggi dengan heteroseksual yaitu 17267 (62,5\%) orang. ${ }^{4}$

Propinsi Papua pada tahun 2014 memiliki tingkat prevalensi tertinggi dari semua Provinsi di Indonesia yaitu 359,42/ 100.000 penduduk. Angká ini akan terus meningkat apabila intervensi yang dilakukan tidak signifikan. Untuk itu perlu dikaji kembali strategi yang selama ini dilakukan, salah satunya perlu mengubah jalannya epidemiologi infeksi HIV selain terus melaksanakan program pendampingan, perawatan dan pengobatan. Pemberian obat Anti Retroviral (ARV) menjadi satu jalan untuk menanggulangi pandemi HIV.

Penemuan obat Anti Retroviral (ARV) pada tahun 1996 mendorong suatu revolusi dalam perawatan ODHA di negara maju. ${ }^{7}$ Berdasarkan data yang dilaporkan dari WHO bahwa pada tahun 2012 sekitar 1,6 juta yang sudah terapi ARV. Dalam memulai ARV dengan tingkat CD4nya mencapai 350 $\mathrm{sel} / \mathrm{mm}^{3}$. Namun, pada tahun 2013 WHO meluncurkan dalam buku pedoman ARV direkomendasikan bahwa untuk memulai ARV jumlah CD4 nya $\leq 500 \mathrm{sel} / \mathrm{mm}^{3,8}$

Provinsi Papua pada Triwulan III Tahun 2013, kumulatif pasien ODHA yang masih dalam terapi antiretroviral sebanyak $62 \%$ (1.966 orang) dan untuk pasien ODHA yang pernah memulai terapi anti retroviral sebanyak 35\% (3.727 orang). Kumulatif kasus HIV/AIDS di Kota Jayapura pada Triwulan III Tahun 2013 berjumlah 3.242 kasus, yang terdiri dari 379 kasus HIV, 2.863 kasus AIDS dan jumlah kematian 172 kasus. KumulatifPasien HIV di Kota Jayapura yang menjalani pengobatan ARV dilaporkan berdasarkan laporan Triwulan III Tahun 2013 mengalami penurunan, pasien yang pernah melakukan terapi sebanyak 1.187 orang menurun menjadi 572 orang yang masih dalam terapi ARV. ${ }^{9}$

Dari seluruh Rumah Sakit yang ada di Kota Jayapura RSUD Abepura memiliki jumlah kasus HIV/AIDS paling tinggi yaitu 300 orang yang terdiri dari 41,67\% laki laki, perempuan 58,33\%. Tahun 2013 ada peningkatan sedikit jumlah kasus yaitu 311 kasus yang terdiri dari 37,62 \% laki-laki dan $62,38 \%$ perempuan.

Data yang diperoleh dari Bagian VCT RSUD Abepura bahwa pada tahun 2012 jumlah pasien HIV yang sedang menjalani pengobatan ARV dan dinilai kepatuhan minum obat ARV sebanyak $146(48,66 \%)$ orang dengan tingkat kepatuhan pengobatan $>95 \%$ berjumlah $63(45,7 \%)$ orang dan tingkat kepatuhan pengobatan $\leq 95 \%$ berjumlah $54(39,1 \%)$ yang LVU terlapor 47 
orang $(32,2 \%)$ dan yang meninggal selama menerima pengobatan ARV ada 26 orang $(15,2 \%)$ yang terdiri dari 13 orang $(8,9 \%)$ laki - laki dan 13 orang (8,9\%) perempuan termasuk LVU.

Tahun 2013 ada peningkatan pasien HIV yang sedang menjalani pengobatan ARV dan dinilai kepatuhan minum obat ARV yaitu $148(47,43 \%)$ orang dengan tingkat kepatuhan pengobatan $>95 \%$ berjumlah 50 $(34,96 \%)$ orang dan tingkat kepatuhan pengobatan $\leq 95 \%$ berjumlah $32(22,38 \%)$ orang, LVU tahun 201340 orang $(27,03 \%)$, yang meninggal selama menerima pengobatan ARV 13 orang $(8,8 \%)$ orang, rujuk keluar $8(5,4 \%)$, dan yang stop pengobatan 2 orang $(1,3 \%)$. Tahun 2014 belum terlaporkan. ${ }^{14}$

Salah satu faktor penting yang perlu diperhatikan adalalah kepatuhan pasien. Kepatuhan atau adherence pada terapi merupakan sesuatu keadaan dimana pasien mematuhi pengobatannya atas dasar kesadaran sendiri, bukan hanya mematuhi perintah dokter. Hal ini penting karena diharapkan akan lebih meningkatkan tingkat kepatuhan minum obat.

Menurut laporan dari WHO pada tahun 2003, kepatuhan rata - rata pasien pada terapi jangka panjang terhadap penyakit kronis di negara maju hanya sebesar $50 \%$ sedangkan di negara berkembang jumlah tersebut bahkan lebih rendah. ${ }^{12}$ Ketidakpatuhan pasien pada terapi ARV dapat memberikan efek negatif yang sangat besar karena prosentase penyakit HIV/AIDS mencapai 54 $\%$ dari seluruh penyakit ditahun 2001. Angka ini bahkan diperkirakan akan meningkat menjadi lebih dari $65 \%$ pada tahun $2020 .^{13}$

Penelitian yang dilakukan di AS dapat dilihat bahwa walau dengan kepatuhan diatas $95 \%$, hanya $81 \%$ orang mencapai viral load yang tidak terdeteksi (kepatuhan 95\% ini berarti hanya lupa atau terlambat memakai 3 dosis per bulan dengan jadwal dua kali sehari). ${ }^{12}$

Faktor-faktor yang mempengaruhi atau faktor prediksi kepatuhan meliputi fasilitas layanan kesehatan (sistem pembiayaan,ruangan yang nyaman, jaminan kera- hasian, sikap petugas), karakteristik pasien (sosiodemografi dan faktor kesehatan jiwa, penggunaan napza, lingkungan dan dukungan ssosial, pengetahuan, perilaku terhadap HIV dan terapinya), panduan terapi, karakteristik penyakit penyerta dan hubungan pasien dengan tenaga kesehatan. Kepatuhan pasien sangatlah penting, maka perlu dilakukan penelitian yang dapat membuktikan faktor - faktor yang menjadi penyebab ketidak patuhan pasien sebagai kunci suksesnya terapi ARV yang pada akhirnya dapat meningkatkan kualitas hidup ODHA.

Tujuan dari penelitian ini adalah untuk mengetahui beberapa faktor yang mempen garuhi kepatuhan terapi antiretroviral (ARV) pada pasien HIV/AIDS di RSUD Abepura, sehingga pada akhirnya hasil penelitian ini dapat dijadikan bahan untuk meningkatkan angka kepatuhan pasien HIV/AIDS guna tercapainya tujuan terapi yang diharapkan.

\section{Metode}

Penelitian ini menggunakan jenis penelitian obserasional analitik, dengan desain penelitian case control adalah penelitian untuk membuktikan secara epidemiologi penyebab terjadinya penyakit. Kedua kelompok dibandingkan dalam hal adanya penyebab atau pengalaman masa lalu yang relevan dengan penyebab penyakit.14

Pada studi ini dilakukan pendekatan retrospektif yang diawali dengan pengambilan data kasus yaitu pasien HIV/AIDS yang tidak patuh menjalani terapi ARV dan kontrol yaitu pasien HIV/AIDS yang patuh menjalani terapi ARV. Kemudian dilakukan teknik pengambilan sampel secara simple random sampling yaitu kelompok kasus dan kelompok kontrol memiliki kesempatan yang sama untuk terpanjan oleh faktor risiko, dengan cara melakukan pengundian baik kelompok kasus maupun kontrol. Penelitian ini juga didukung dengan data kualitatif untuk menjelaskan mengapa dan bagaimana faktor risiko itu terjadi. Pengumpulandata kualitatif dilakukan 
dengan menggunakan indepth interview.

Pengambilan data dilakukan dengan mewawancarai pasien dengan kuesioner dengan tujuan untuk mengetahui faktor faktor yang mempengaruhi kepatuhan terapi antiretroviral (ARV) pada pasien HIV/AIDS.

Sampel penelitian sebanyak 86 orang yang terbagi menjadi 43 kasus dan 43 kontrol, kemudian diteliti secara retrospektif beberapa faktor risiko yang berpengaruh terhadap kepatuhan terapi ARV pada pasien HIV/AIDS.

Kritera inklusi kasus adalah penderita HIV/AIDS yang sedang menjalani ter api ARV yang dinilai kepatuhan (adherence) berada $<95 \%$ (tidak patuh) berdasarkan data Laporan Bulanan Perawatan dan ART sampai dengan tahun 2013, rutin mengambil obat tiap bulan, bersedia menjadi responden dan dapat berkomunikasi. Kontrol adalah penderita HIV/AIDS yang sedang menjalani terapi ARV di Klinik VCT RSUD Abepura dan be rdasarkan data Laporan Bulanan Perawatan HIV dan ART tahun 2013 yang dinilai kepatuhannya (adherence) berada $>95 \%$ serta rutin mengambil obat tiap bulan, bersedia menjadi responden. Kriteria eksklusi Kasus dan kontrol yaitu penderita sedang mengalami /terapi pengobatan kasus jiwa.

Pengolahan dan analisa data dilakukan dengan sistem komputer program SPSS for windows terdiri dari analisa univariat, bivariat dan multivariat.

Penelitian ini dimintakan persetujuan dari Komisi Etik Penelitian Kesehatan Fakultas Kedokteran Universitas Diponegoro/RSUP Dr. Karyadi Semarang No.415// EC/FK-RSDK/2014.

\section{Hasil}

Dari penelitian yang dilakukan pada bulan Agustus - Oktober 2015 diKlinik VCT RSUD Abepura pada 86 responden diperoleh hasil dengan analisa univariat, bivariat dan multivariat sebagai berikut :

\section{Hasil Analisis Univariat}

Analisis univariat dilakukan untuk mendeskripsikan variabel terikat kepatuhan terapi ARV) dan variabel bebas menggunakan tabel distribusi frekuensi, seperti disajikan pada Tabel 1.

\section{Gambaran umum variabel pada res- ponden kasus dan kontrol}

Tabel 1.Gambaran berdasarkan umur pada responden kasus dan kontrol

\begin{tabular}{lrr}
\hline Karakteristik & \multicolumn{1}{c}{ Kasus } & \multicolumn{1}{c}{ Kontrol } \\
43 & \multicolumn{1}{c}{43} \\
\hline Mean & 33,65 & 34,09 \\
Median & 30,00 & 30,00 \\
Maximum & 18 & 16 \\
Minimal & 45 & 65 \\
\hline
\end{tabular}

Tabel 1. menunjukan bahwa rata-rata umur pasien HIV/AIDS yang tidak patuh menjalani terapi ARV adalah 33 tahun, sedangkan yang patuh rata - rata umurnya 34 tahun. Pasien yang tidak patuh paling muda umur 18 tahun dan paling tua umur 45 tahun, sedangkan yang patuh paling muda umur 16 tahun dan paling tua umur 65 tahun.

Tabel 2. Gambaran berdasarkan pekerjaan pada responden kasus dan kontrol

\begin{tabular}{lrrrr}
\hline \multirow{2}{*}{ Pekerjaan } & \multicolumn{4}{c}{ Kepatuhan } \\
\cline { 2 - 5 } & $\begin{array}{l}\text { Tidak } \\
\text { Patuh }\end{array}$ & $\%$ & Patuh & $\%$ \\
\hline IRT & 4 & 9,3 & 9 & 20,9 \\
PNS & 4 & 9,3 & 6 & 14,0 \\
TNI/POLRI & 1 & 2,3 & 0 & 0 \\
Pedagang & 10 & 23,3 & 6 & 14,0 \\
Petani & 2 & 4,7 & 1 & 2,3 \\
Buruh & 2 & 4,7 & 1 & 2,3 \\
Karyawan LSM & 0 & 0 & 2 & 4,7 \\
Tidak Bekerja & 16 & 37,2 & 13 & 30,2 \\
PSK & 0 & 0 & 1 & 2,3 \\
Mahasiswa/Pelajar & 4 & 9,3 & 4 & 9,3 \\
& 43 & 100 & 43 & 100 \\
\hline
\end{tabular}


Berdasarkan Tabel 2. menunjukan bahwa proporsi responden yang tidak bekerja banyak yang tidak patuh sebesar 37,2 $\%$, kemudian yang status pekerjaan sebagai pedagang $23,3 \%$ dan status kerja sebagai ibu rumah tangga, PNS dan mahasiswa memiliki proporsi yang sama yaitu $9,3 \%$, sama halnya dengan status kerja sebagai petani dan buruh juga memiliki proporsi yang sama 4,7 \%. Sedangkan proporsi responden yang patuh banyak pada responden dengan status tidak bekerja 30,2\%, yang status pedagang dan ibu rumah tangga hampir mendekati 20,9\%, kemudian status kerja sebagai PNS 14,0\%, status kerja mahasiswa/pelajar 9,3\%, karyawan LSM 4,7\% dan status kerja sebagai PSK, buruh serta petani memiliki proporsi yang sama yaitu $2,3 \%$.

\section{Distribusi frekuensi beberapa faktor pada responden kasus dan kontrol}

Distribusi frekuensi beberapa faktor baik pada responden kasus maupun kontrol dapat dilihat pada Tabel3.

\section{Hasil Analisis Bivariat}

Analisis bivariat dilakukan untuk melihat adanya pengaruh antara variabel bebas dengan variabel terikat melalui nilai "p" (nilai $p<0,05$ ) yang menunjukan signifikansi variabel. Besarnya nilai odds ratio (OR) untuk mengetahui apakah variabel bebas yang diuji merupakan faktor risiko atau bukan bagi variabel terikat.

Berdasarkan uji chi - square pada analisis bivariat diperoleh hasil bahwa ada tiga variabel yang berpengaruh terhadap kepatuhan terapi ARV pada pasien HIV/AIDS yaitu variabel pekerjaan status bekerja $(\mathrm{p}=0,005 ; \mathrm{OR}=4,472 ; 95 \% \mathrm{CI}=$ 1,63-12,24), sulit akses ke pelayanan kesehatan $(\mathrm{p}=0,008 ; \mathrm{OR}=3,675 ; 95 \% \mathrm{CI}=$
1,63-12,24), sulit akses ke pelayanan kesehatan $(\mathrm{p}=0,008 ; \mathrm{OR}=3,675 ; 95 \% \mathrm{CI}=$ $1,47-9,146)$, dukungan keluarga $(\mathrm{p}=0,013$; $\mathrm{OR}=3,606 ; 95 \% \mathrm{CI} ; 1,398-9,299)$. Lebih jelasnya dapat dilihat pada

\section{Hasil Analisis Multivariat}

Analisis multivariat dilakukan untuk mengetahui independent variable yang paling berpengaruh terhadap kepatuhan terapi ARV dan menentukan model persamaan terbaik. Analisis dilakukan dengan uji regresi logistik ganda (Multiple Logistic Regresion) dengan menggunakan metode enter.

Kriteria penilaian dalam pemilihan variabel penting yang dipakai untuk memasukkan variabel bebas ke dalam analisis multivariat dengan memperhitungkan nilai $\mathrm{p}<0,25$. Ada 6 variabel yang masuk dalam kriteria yaitu pekerjaan dengan status bekerja, pengetahun kurang, sulit akses ke layanan kesehatan memperoleh ARV, lama terapi $>2$ tahun, sikap petugas kesehatan kurang, tidak ada dukungan keluarga. Selanjutnya dilakukan analisis interaksi secara bersama-sama untuk melihat kemungkinan adanya interaksi antar variabel. Persamaan model terbaik dipertimbangkan dengan nilai signifikansi $\mathrm{p}<0,05$.

Hasil analisis multivariat ini menunjukkan bahwa variabel bebas yang penting setelah dianalisis secara bersamasama sebanyak 6 variabel yang terbukti sangat kuat berpengaruh terhadap kepatuhan terapi antiretroviral pada pasien HIV/AIDS ada 3 variabel yaitu : variabel pekerjaan status bekerja, sulit akses ke layanan kesehatan memperoleh ARV, tidak ada dukungan keluarga. Untuk hasil analisis multivariat selengkapnya dapat dilihat pada Tabel 5. 
Tabel 3. Distribusi Frekuensi beberapa faktor pada responden kasus dan kontrol

\begin{tabular}{ccccc}
\hline \multirow{2}{*}{ Karakteristik Subyek } & \multicolumn{2}{c}{ Kasus } & \multicolumn{2}{c}{ Kontrol } \\
\cline { 2 - 5 } & $\mathrm{n}=43$ & $\%$ & $\mathrm{n}=43$ & $\%$ \\
\hline
\end{tabular}

1. Jenis Kelamin

Laki-Laki

Perempuan

2. Umur

Risiko tinggi $(<30)$

Risiko rendah $(\geq 30)$

3. Pekerjaan

$$
\begin{aligned}
& \text { Bekerja } \\
& \text { Tidak Bekerja }
\end{aligned}
$$

4. Pengetahuan

Kurang

Baik

5. Sikap apatis pasien

Kurang baik

Baik

6. Riwayat efek samping

Ada riwayat

Tidak ada riwayat

7. Lama terapi

$$
>2 \text { tahun }
$$

$\leq 2$ tahun

8. Akses ke layanan kesehatan memperoleh ARV

$$
\text { Sulit }
$$

Mudah

9. Sikap nakes

konseling ARV

Kurang baik

Baik

10. Latar belakang suku nakes konseling ARV

Bukan Papua

Suku Papua

11. Pendekatan Agama

Tidak Ada

Ada

12. Dukungan Keluarga

Tidak Ada

Ada

13. Penggunaan obat alternatif

Menggunakan

Tidak gunakan

14. Penggunaan obat herbal

Menggunakan

Tidak gunakan

17

26

39,5

60,5

19

24

20

23

23

20

12

31

30

13

13

30

24

19

55,8

44,2

55,8

46,5

53,5

53,5

46,5

27,9

72,1

69,8

30,2

30,2

69,8

44,2

16,3

83,7

36

15

28

27

16

21

22

\begin{tabular}{rrrr}
2 & 4,7 & 2 & 4,7 \\
41 & 95,3 & 41 & 95,3 \\
& & & \\
9 & 20,9 & 7 & 16,3 \\
34 & 79,1 & 36 & 83,7 \\
\hline
\end{tabular}

$15 \quad 34,9$

$28 \quad 65,1$

22

51,2

48,8

16,3

83,7

16

37,2

62,8

$14 \quad 32,6$

$29 \quad 67,4$

32

74,4

$11 \quad 25,6$

21

48,8

51,2

25,6

74,4

32

4,7

4195,3

$34,9 \quad 11$

25,6

65,1

32

74,4

$62,8 \quad 25$

58,1

37,2

18

41,9

48,8

20,9

51,2

9

79,1

$34 \quad 79,1$

4,7

83,7 
Tabel 4. Analisis Bivariat Beberapa Faktor yang Mempengaruhi Kepatuhan Terapi ARV pada Pasien HIV/AIDS

\begin{tabular}{lllllllll}
\hline \multirow{2}{*}{ No. } & \multirow{2}{*}{ Variabel } & \multicolumn{2}{c}{ Kasus } & \multicolumn{2}{c}{ Kontrol } & \multirow{2}{*}{ OR } & $95 \% \mathrm{CI}$ & $\mathrm{p}$ \\
\cline { 2 - 5 } & $\mathrm{n}$ & $\%$ & $\mathrm{n}$ & $\%$ & & & \\
\hline
\end{tabular}

1. Jenis Kelamin

Laki-Laki

Perempuan

2. Umur

Risiko tinggi $(<30)$

Risiko rendah $(\geq 30)$

3. Pekerjaan

Bekerja
Tidak Bekerja

4. Pengetahuan

Kurang
Baik

5. Sikap apatis pasien

Kurang baik

Baik

6. Riwayat efek samping

Ada riwayat

Tidak ada riwayat

7. Lama terapi

$>2$ tahun

$\leq 2$ tahun

8. Akses ke layanan kesehatan memperoleh ARV

\section{Sulit \\ Mudah}

9. Sikap nakes konseling ARV

Kurang baik

Baik

10. Latar belakang suku nakes

konseling ARV

Bukan Papua

Suku Papua

11. Pendekatan Agama

Tidak Ada

Ada

12. Dukungan Keluarga

Tidak Ada

Ada

$\begin{array}{lllllll}17 & 39,5 & 15 & 34,9 & 1,221 & 0,508-2,93 & 0,823 \\ 26 & 60,5 & 28 & 65,1 & & & \end{array}$

$19 \quad 44,2 \quad 22 \quad 51,2 \quad 0,756 \quad 0,32-1,765 \quad 0,666$

$\begin{array}{llll}24 & 55,8 & 21 & 48,8\end{array}$

$\begin{array}{rrrrrrr}20 & 46,5 & 7 & 16,3 & 4,472 & 1,63-12,24 & 0,005 \\ 23 & 53,5 & 36 & 83,7 & & & \end{array}$

$23 \quad 53,5 \quad 16 \quad 37,2 \quad 1,941 \quad 0,82-4,59 \quad 0,194$

$\begin{array}{llll}20 & 46,5 & 27 & 62,8\end{array}$

$\begin{array}{lllllll}12 & 27,9 & 14 & 32,6 & 0,802 & 0,31-2,017 & 0,814\end{array}$

$31 \quad 72,1 \quad 29 \quad 67,4$

$\begin{array}{lllllll}30 & 69,8 & 32 & 74,4 & 0,793 & 0,30-2,041 & 0,810\end{array}$

$13 \quad 30,2 \quad 11 \quad 25,6 \quad 0,793 \quad 0,30-2,041 \quad 0,793$

$\begin{array}{lllllll}13 & 30,2 & 21 & 48,8 & 0,454 & 0,18-1.099 & 0,123\end{array}$

$\begin{array}{llll}30 & 69,8 & 22 & 51,2\end{array}$

$24 \quad 55,8 \quad 11 \quad 25,6 \quad 3,675 \quad 1,47-9,146 \quad 0,008$

$19 \quad 44,2 \quad 32 \quad 74,4$

$\begin{array}{lllllll}7 & 16,3 & 2 & 4,7 & 3,966 & 0,77-20,42 & 0,159\end{array}$

$\begin{array}{llll}36 & 83,7 & 41 & 95,3\end{array}$

$\begin{array}{lllllll}15 & 34,9 & 11 & 25,6 & 1,558 & 0,61-3,945 & 0,481\end{array}$

$28 \quad 65,1 \quad 32 \quad 74,4$

$\begin{array}{lllllll}27 & 62,8 & 25 & 58,1 & 1,215 & 0,51-2,888 & 0,825\end{array}$

$\begin{array}{llll}16 & 37,2 & 18 & 41,9\end{array}$

$\begin{array}{lllllll}21 & 48,8 & 9 & 20,9 & 3,606 & 1,39-9,299 & 0,013\end{array}$

$\begin{array}{llll}22 & 51,2 & 34 & 79,1\end{array}$ 


\begin{tabular}{|c|c|c|c|c|c|c|c|c|}
\hline \multirow{2}{*}{ No. } & \multirow{2}{*}{ Variabel } & \multicolumn{2}{|c|}{ Kasus } & \multicolumn{2}{|c|}{ Kontrol } & \multirow{2}{*}{ OR } & \multirow{2}{*}{$95 \% \mathrm{CI}$} & \multirow{2}{*}{$\mathrm{p}$} \\
\hline & & $\mathrm{n}$ & $\%$ & $\mathrm{n}$ & $\%$ & & & \\
\hline \multirow[t]{3}{*}{13.} & Penggunaan obat altern & & & & & & & \\
\hline & Menggunakan & 2 & 4,7 & 2 & 4,7 & 1,000 & $0,13-7,442$ & 1,000 \\
\hline & Tidak menggunakan & 41 & 95,3 & 41 & 95,3 & & & \\
\hline \multirow[t]{3}{*}{14.} & Penggunaan obat herbal & & & & & & & \\
\hline & Menggunakan & 9 & 20,9 & 7 & 16,3 & 1,361 & $0,45-4,062$ & 0,782 \\
\hline & Tidak menggunakan & 34 & 79,1 & 36 & 83,7 & & & \\
\hline
\end{tabular}

Tabel 5. Hasil akhir model uji analisis regresi logistik

\begin{tabular}{clccccc}
\hline No. & \multicolumn{1}{c}{ Variabel Independent } & B & Wald & P & OR & OR \\
\hline 1. & Pekerjaan status bekerja & 1,463 & 6,989 & 0,008 & 4,318 & $1,460-12,771$ \\
2. & Sulit ke layanan kesehatan & 1,332 & 6,792 & 0,009 & 3,790 & $1,391-10,323$ \\
& mendapatkan ARV $((\geq 20 \mathrm{~km})$ & & & & & \\
3. & Tidak ada dukungan keluarga & 1,334 & 6,326 & 0,013 & 3,798 & $1,343-10,744$ \\
& Constant & $-2,668$ & 14,912 & 0,001 & 0,237 & \\
\hline
\end{tabular}

\section{Pembahasan}

Hasil analisis multivariat menunjukkan bahwa dari ke enam variabel yang dianalisis secara bersama-sama yakni pekerjaan (status bekerja), pengetahuan (kurang), lama terapi $>2$ tahun, sulit akses ke layanan kesehatan memperoleh ARV, sikap tenaga kesehatan yang kurang baik, tidak ada dukungan keluarga hanya terdapat tiga variabel yang terbukti merupakan faktor risiko kuat terjadinya ketidakpatuhan terapi ARV pada pasien HIV/AIDS yang mempunyai nilai $\mathrm{p}<0,05$.

Hasil uji regresi logistik model akhir menunjukan bahwa faktor pekerjaan (status bekerja) terbukti kuat secara statistik sebagai faktor yang berpengaruh terhadap kepatuhan terapi ARV pada pasien HIV/AIDS ( $p$ : 0,008 ) dengan adjusted OR sebesar 4,318 dengan $95 \%$ CI (1,460-12,771). Artinya bahwa Pasien HIV/AIDS yang status pekerjaan bekerja memiliki 4,318 kali lebih besar untuk tidak patuh menjalani terapi ARV dibandingkan yang tidak bekerja. Hasil penelitian ini sejalan dengan penelitian yang dilakukan oleh Sasmita di RSUP Kariadi Semarang menunjukan bahwa hambatan dalam pengobatan ARV adalah sebanyak
$37,2 \%$ responden kesulitan dalam menin gglkan pekerjaan bila harus mengambil obat ARV. Hambatan lain adalah 30\% takut dikeluarkan dari pekerjaan bila sering izin untuk mengambil obat. Di dukung juga dengan penelitian lainnya yaitu kepatuhan di negara maju dan berkembang menemukan kesamaan kendala individu pada kepatuhan ; lupa memakai obat karena terlalu sibuk, alasan lain mengganggu aktivitas sehari-hari. ${ }^{16}$

Faktor sulitnya akses ke layanan kesehatan untuk memperoleh ARV juga berpengaruh terhadap kepatuhan terapi ARV yaitu (nilai $p=0,009$ ) berpengaruh terhadap kepatuhan terapi dengan (nilai OR 3,790 pada $95 \%$ CI : 1,391-10,323). Artinya bahwa pasien HIV/AIDS yang sulit akses ke layanan kesehatan memperoleh ARV memiliki risiko 3,79 kali untuk tidak patuh terapi ARV dibandingkan yang mudah mengakses layanan kesehatan memperoeh ARV.

Hasil penelitian ini sejalan dengan penelitian yang dilakukan oleh Martoni yang mengatakan bahwa ada hubungan akses ke layanan kesehatan untuk memperoleh ARV dengan kepatuhan terapi ARV nilai $p=0,02$. Sama halnya dengan penelitian bersama 
yang dilakukan oleh Fithtria bahwa faktor akses atau jarak dari rumah ke rumah sakit berpengaruh terhadap kepatuhan ARV ( $\mathrm{p}=$ 0,049). Pasien sulit menjangkau karena transportasi yang susah $(\mathrm{p}=0,019)$ serta biaya trasportasi yang tidak dapat dijangkau $(p=0,006) .^{17,18}$

Di Uganda salah satu kendala yang dihadapi pasien HIV adalah tempat tinggal yang jauh dari layanan kesehatan sehingga mereka diberikan bantuan berupa uang transportasi ke klinik atau menyediakan layanan perawatan berbasis rumah. ${ }^{19}$

Faktor tidak ada dukungan keluarga juga terbukti berpengaruh terhadap kepatuhan terapi ARV $p$ ada pasien HIV/AIDS yaitu nilai ( $p: 0,013$ dengan nilai OR: 3,798 pada 95\%CI: 1,343-10,774). Artinya bahwa pasien hiv/aids yang tidak mendapatkan dukungan keluarga memiliki risiko 3,798 kali untuk tidak patuh dibandibandingkan yang mendapatkan dukungan keluarga.

Penelitian ini sejalan dengan penelitian lain yang menunjukkan bahwa ada hubungan dukungan sosial dengan kepatuhan terapi ARV dimana, dukungan dari anggota keluarga dan teman terdekat merupakan salah satu dukungan yang sangat diperlukan terhadap pelaksanaan terapi ARV dan berpengaruh besar bagi ODHA untuk memacu semangat hidupnya. ${ }^{20}$

Peneliti Andreas Goo berpendapat bahwa di daerah Pedalaman Papua, keluarga dekat adalah tempat yang paling aman untuk menceritakan rahasia tentang status seseorang. Penelitiannya membuktikan bahwa anggota keluarga akan memberikan empati, memberikan tempat untuk tidur dan tinggal, berbagi pakaian, piring dan fasilitas mandi, dan bahkan berdoa bersama-sama. Keluarga dapat juga melindungi ODHA dari stigmatisasi. Ketika keluarga berempati dan menerima status ODHA, dukungan tersebut kelihatannya merupakan norma yang berlaku. $^{21}$

Keterbatasan pada penelitian ini karena kasus dan kontrol bersifat retrospektif, sehingga recall bias tidak dapat dihindari. Upaya untuk meminimalkan recall bias adalah melakukan komunikasi lebih intens untuk membantu responden mengingat kejadian-kejadian yang dialami.

Kesalahan pada saat melakukan wawancara. Kesalahan ini terjadi apabila pewawancara kurang jelas dalam memberikan pertanyaan. Cara untukmenga tasinya dengan mengulangi pertanyaan atau menjelaskan yang tidak jelas tersebut dengan menggunakan bahasa yang lebih mudah dimengerti oleh responden tanpamerubah makna/isi pertanyaan tersebut.

Keterbatasan dalam pengumpulan data (Non Response Bias). Ada beberapa responden yang sudah ditentukan dengan teknik pengambilan sampel secara random sebagai sampel namun mereka menolak untuk berpartisipasi dalam studi dan tidak bisa ditemui. Cara mengatasinya kita menggantikan dengan responden lain dengan cara menunggu pasien di klinik, setelah pasien mendapatkan pelayanan kemudian dengan bantuan perawat yang sedang bertugas dirujuk ke peneliti dengan memperhatikan kriteria sampel penelitian.

\section{Kesimpulan}

Berdasarkan hasil penelitian dapat disimpulkan bahwa faktor - faktor yang terbukti berpengaruh terhadap kepatuhan terapi ARV pada pasien HIV/AIDS adalah pekerjaan dengan 4,318 kali tidak patuh menjalani terapi ARV, sulit akses ke layanan kesehatan memperoleh ARV, dengan risiko 3,79 kali untuk tidak patuh terapi ARV dan tidak ada dukungan keluarga, dengan risiko 3,798 kali untuk tidak patuh dibandingkan yang mendapatkan dukungan keluarga.

\section{Ucapan Terimakasih}

Terimakasih kepada pihak RSUD Abepura, Jayapura yang telah memberikan ijin penulis dalam proses pengumpulan data. 


\section{Daftar Pustaka}

1. Djoerban, Z \& Djauzi S. 2006. Buku Ajar Ilmu Penyakit Dalam, Cetakan Ke II. BAB. 405 HIV/AIDS di Indonesia. Jakarta : Pusat Penerbitan Departemen Ilmu Penyakit Dalam. Depok: Fakultas Kedokteran UI. pp. 1803-1807.

2. Brasshers V L . 2008. Aplikasi Klinis Patofisiologi Pemeriksaan dan Manajemen. Bab.27 Penyakit HIV. Jakarta: EGC.pp. 389-93UNAIDS.

3. UNAIDS. 2012. World AIDS Day Report. 2012, Geneva: UNAIDS

4. Kemenkes RI. 2013. Statistik Kasus HIV/AIDS di Indonesia dilapor s/d Desember 2013. Jakarta: Dirtjen PP \& PL: Jakarta.

5. Kemenkes RI. 2014. Statistik Kasus HIV/AIDS di Indonesia Dilapor s/d September 2014. Jakarta: Ditjen PP \& PL.

6. Margarita. 2007. Konseling, Dukungan, Perawatan dan Pengobatan ODHA. Surabaya: Airlangga University Press.

7. UNICEF. 2012. Multiple Indicator Cluster Survey Kabupaten Terpilih di Papua dan Papua Barat. Temuan Kunci Awal. Badan Pusat Statistik Papua.

8. WHO. 2012. Global Up Date On HIV Treatment, Result, Impact and Oppurtunities 2013. WHO Report in Partnership With UNICEF and UNAIDS. Dinkes. Laporan Komulatif Kasus HIV/AIDS.

9. Dinas Kesehatan Provinsi Papua. 2013. VCT RSUD Abepura, Data Kunjungan Pasien HIV/AIDS yang sedang Terapi Antiretroviral (ARV).Abepura: Kota Jayapura.

10. Kemenkes RI. 2011. Pedoman Tata Laksana K linis Infeksi HIV dan Terapi Antiretroviral pada Orang Dewasa. Jakarta: Dirtjen Pengendalian Penyakit \& Penyehatan Lingkungan.

11. Badan POM RI. 2006. Kepatuhan Pasien: Faktor Penting Dalam Keberhasilan Terapi. Info POM Vol.7,No.5.

12. Depkes RI.2006. PedomanPelayanan Kefarmasian Untuk Orang HIV/AIDS (ODHA). Jakarta: Dirtjen Kefarmasian \& Alat Kesehatan.
13. Haroutune AK. 2010. The Case Control Method. Design and Applications. California: Oxord University Press.pp.17-29.

14. Sasmita, H.A.2010. Faktor-Faktor yang Mempengaruhi Kepatuhan HIV-AIDS Terhadap Terapi Antiretroviral di RSUP Dr.Karyadi.Semarang: Universitas Diponegoro

15. Mills EJ, Nachega JB, Bangsberg DR, Singh S, Rachlis B, Wu P, et al. 2006. Adherence to HAART: A Systematic Review of Developed and Developing Nation Patient-Reported Barriers and Facilitators. Plos Medicine. Vol.3(11).

16. Martoni W. 2012. Faktor-Faktor yang Mempengaruhi Kepatuhan Pasien HIV/ AIDS di Poliklinik Khusus Rawat Jalan Bagian Penyakit Dalam RSUP Dr. M.Djamil Padang.

17. Fithria RF, Purnomo A, Ikawati Z. 2011. Faktor-Faktor yang Mempengaruhi Tingkat Kepatuhan Pengobatan ARV (Antiretroviral) pada ODHA (Orang Dengan HIV/AIDS) di Rumah Sakit Umum Daerah Tugurejo dan Rumah Sakit Umum Panti Wiloso. Manajemen dan Pelayanan Farmasi Vol.1, No.2.

18. Jaffar S.2009. Rates of Virological Failure in Patients Treated in a Home-Based Versus a Facility-Based HIV-Care Model in Jinja, Southeast Uganda: a Cluster-Randomisedequivalence Trial Lancet 374.pp.2080-2 089. Public Medical Central.

19. Mahardining AB. 2010. Hubungan antara Pengetahuan, Motivasi, dan Keluarga dengan Kepatuhan Terapi Antiretroviral Pada ODHA. Kesmas Vol.5.No.2;

20. Butt L, Morin J, Numbery G, Peyon I, Goo A,.2010. Stigma dan HIV/AIDS di Wilayah Pegunungan Papua. Canada: Pusat Studi Kependudukan: Kerjasama Universitas Cenderawasih Jayapura \& University of Victoria. 